\title{
Continuous positive pressure on aircraft in neonates: care provided by the nursing team ${ }^{a}$
}

\author{
Pressão positiva contínua nas vias aéreas em neonatos: cuidados prestados pela equipe de \\ enfermagem \\ Presión positiva continua en las vías aéreas en neonatos: cuidados prestados por el equipo de \\ enfermería
}

\begin{abstract}
Bruna Luizy dos Santos Guedes ${ }^{1}$ Marcella Martins Barbosa Ferreira² Mércia Lisieux Vaz da Costa Mascarenhas ${ }^{1}$

Anne Laura Costa Ferreira ${ }^{1}$

Luana Cavalcante Costa ${ }^{1}$

Ingrid Martins Leite Lúcio ${ }^{1}$

1. Universidade Federal de Alagoas. Maceió,

AL, Brasil.

2. Universidade Estadual de Ciências da Saúde de Alagoas. Maceió, AL, Brasil.
\end{abstract}

Corresponding author:

Bruna Luizy dos Santos Guedes.

E-mail: bruna.guedes89@gmail.com.

Submitted on $05 / 16 / 2018$

Accepted on 01/04/2019.

DOI: 10.1590/2177-9465-EAN-2018-0122

\section{Abstract}

Objective: to describe the nursing care of the neonate in continuous positive airway pressure (CPAP) with prong analyzing them in the light of the systematization of nursing care / process. Method: Descriptive research, qualitative approach. We interviewed 30 nursing professionals from the neonatal intensive and intermediate care units of a school hospital in Maceió / Alagoas, from August / 2016 to January / 2017, through a semi-structured interview, in the light of Bardin's content analysis. Results: Although unit nurses are aware of the use of CPAP and the care associated with this therapy, mid-level professionals still find it difficult to systematize systematized knowledge about the system. The tripod's correlation between CPAP, the formation of nasal lesions and the assistance provided was highlighted. Conclusion: It is necessary to carry out training, such as raising the awareness of professionals about the importance of keeping records up to date and applying protocols.

Keywords: Newborn; Continuous Positive Airway Pressure; Nursing Care.

\section{Resumo}

Objetivo: Descrever os cuidados de enfermagem ao neonato em pressão positiva contínua nas vias aéreas (CPAP) com pronga, analisando-os à luz da sistematização da assistência/processo de enfermagem. Método: Pesquisa descritiva, abordagem qualitativa. Foram entrevistados 30 profissionais de enfermagem das unidades de terapia intensiva e intermediária neonatais de um hospital escola de Maceió/Alagoas, de agosto/2016 a janeiro/2017, através de entrevista semiestruturada, à luz da análise de conteúdo de Bardin. Resultados: Embora os enfermeiros das unidades tenham o conhecimento sobre o uso da CPAP e os cuidados inerentes a essa terapêutica, os profissionais de nivel médio ainda sentem dificuldades em elencar de forma sistematizada conhecimentos sobre o sistema. Destacou-se a correlação do tripé entre a CPAP, a formação de lesões nasais e a assistência prestada. Conclusão: Faz-se necessária a realização de capacitações, como sensibilização dos profissionais acerca da importância da manutenção atualizada dos registros e aplicação de protocolos.

Palavras-chave: Recém-Nascido; Pressão Positiva Contínua nas Vias Aéreas; Cuidados de Enfermagem.

\section{Resumen}

Objetivo: describir los cuidados de enfermería al neonato en presión positiva continua en las vías aéreas (CPAP) con preñez analizándolos a la luz de la sistematización de la asistencia / proceso de enfermería. Método: Investigación descriptiva, enfoque cualitativo. Se entrevistó a 30 profesionales de enfermería de las unidades de terapia intensiva e intermedia neonatales de un hospital escuela de Maceió / Alagoas, de agosto / 2016 a enero / 2017, a través de una entrevista semiestructurada, a la luz del análisis de contenido de Bardin. Resultados: Aunque los enfermeros de las unidades tienen el conocimiento sobre el uso de la CPAP y los cuidados inherentes a esa terapéutica, los profesionales de nivel medio todavía sienten dificultades en enumera de forma sistematizada conocimientos sobre el sistema. Se destacó la correlación del trípode entre la CPAP, la formación de lesiones nasales y la asistencia prestada. Conclusión: Se hace necesaria la realización de capacitaciones, como sensibilización de los profesionales acerca de la importancia del mantenimiento actualizado de los registros y aplicación de protocolos.

Palabras clave: Recién Nacido; Presión de las Vías Aéreas Positiva Continua; Atención de Enfermería. 


\section{INTRODUCTION}

Through birth, the neonate passes through several significant physiological adaptations for the adequate maintenance of breathing and, any oxygen supply deprivation, even as a few minutes, can cause irreversible brain damages. For premature neonates, which pulmonary function is still immature, the possibility of respiratory problems increase. ${ }^{1}$ The prematurity and the respiratory discomfort are the main causes of neonates' hospitalization in neonatal intensive care units, representing $53.3 \%$ and $50,5 \%$, respectively ${ }^{2}$. With the aim at avoiding and/ or minimizing risks, there is a need for a specialized care and the suitable choice of the ventilation assistance mode that will be given.

Among the oxygen therapy modalities for neonates it highlights the Continuous Positive Airway Pressure (CPAP, Continuous Positive Airway Pressure as known in English) that consists of continued administration and under pressure of oxygen and compressed air with the aid of nasal devices. Thus, there is an increase of the pulmonary residual functional capacity and reduction of the pulmonary vascular resistance, enabling the maintenance of the positive pressure during expiratory cycle, and thus, the expansion of the alveoli and improvement of the breathing. ${ }^{3}$

The nasal CPAP can be used from birth or after the interruption of the invasive mechanical ventilation. This therapeutic presents as benefit the reduction of the invasive support need, improving pulmonary mechanic-related parameters and reduction of the respiratory work. ${ }^{4,5}$

For this system interfaces are used, such as facial mask, nasal mask, orotracheal and nasopharingeal cannula, short single nasal prong, short nasopharingeal and binasal, and this later is the most used mainly in the northeast region of Brazil due to its easy application in the nasal region of the neonate. ${ }^{1}$

However, its use can also cause some air leak-related complications, resulting in a decline of the offered pressure; to the drying up of the mucous membranes; the low tolerance by the neonate; in addition to barotraumas and abdominal distension. With the prevalence of nasal traumas caused by the CPAP use of 20 to $42.5 \%$ on worldwide level, and have already reached percentages of 85 to $100 \%$ at a national level. ${ }^{1,6}$

We are even concerned about the paranasal lesions related to the skin and nasal septum from the use of the CPAP system, which could vary from: redness, bleeding, formation of crusts, excoriations, narrowing of the air passage and in the most serious cases, columella necrosis with loss of tissue and irreversible sequelae. The lesions caused by the CPAP use in the mode of nasal prong can be classified in three stages: light, in which redness or nasal hyperemia occurs; moderate, with the presence of injuries with bleeding; and severe, which imply the formation of necrosis. ${ }^{7,8,9}$

Faced with the need of care of newborn in intensive and intermediate therapy care unit, it highlights the care related to the nasal CPAP system with prong. For an effective and safe therapeutic to happen, the nursing team who is directly related to the care of this patient must identify the need of oxygenation compromised; plan the Nursing Process (NP), as part of the Systematization of Nursing Care (SNC); and encourage an integral and humanized care respecting the specificities of a neonate patient. ${ }^{10}$

Thus, the SAE is a means of organization of the nursing professional work that involves method, the human resources and adequate instruments. The application of the SNA enables the operationalization of the NP, which reports to a work methodology that offers support to the development of the assistance, based on the scientific method by identifying a problem situation of a client/patient and providing an adequate implementation of nursing care. ${ }^{10,11}$

However, in face of the dominant health models, the nursing adapted its work process to the procedures, techniques and routines, distancing itself, sometimes, from the extended care itself, the teaching and the research for the valorization and growing of the NP as instrument of its practice. On the other hand, for those who can apply the NP in its practice, rises a nursing that base its assistance on theories that can be adequate to the neonatal /pediatric care approaching even more the nursing team to its object of care. ${ }^{12}$

The care result of the nursing team to restore the neonates' health is directly related to the fact that this team is responsible for providing care to the patient in a continuous and interrupted way on a daily basis.. ${ }^{13}$

The research shows itself relevant, even in face of the technological advances in neonatal care the team faces with difficulties in the approach to the neonate undergoing nasal CPAP with prong and with the possible injuries related to its use, which requires investments in the qualification of nursing professionals for the performance of a safe and humanized care, mainly in premature neonates who show differentiated skin and pulmonary system characteristics in order to avoid the presence of traumas and injuries in the nasal region, that can be caused by the ventilation assistance given.

From experiences in the assistance practice and considering the notes of the literature on the high incidence of nasal injuries in neonates undergoing nasal CPAP with prong and its correlation with the nursing care, the following leading question has arisen: How are performed the nursing care to the neonate undergoing nasal CPAP with prong considering the SAE? On search for answers for this question, it was established as objective to describe the nursing care to the neonate undergoing CPAP with prong analyzing in the light of the SNC/ nursing process.

\section{METHOD}

This is a descriptive study, with qualitative approach ${ }^{14}$. The scenarios were the Conventional Neonatal Intermediate Care Units (CNICU) and Neonatal Intensive Therapy Unit (NITU), of a teaching hospital, reference to the Alagoas State for maternal- 
-child high-risk assistance, linked to the Single Health System.

The research subjects were 30 professionals of the nursing team (superior, technician and aid level) effectives, interviewed between the months August 2016 and January 2017. The inclusion criteria were nursing team professionals of the CNICU and NITU who were on duty during the data collection period. The exclusion criteria were professionals and residents who performed management positions. The units have 66 professionals as total, the losses during the research occurred, mainly, because the professionals have refused to participate in the research.

This research passed through all the processes necessary to the researches with human being. Thus, the data collection began after approval by the Research Ethics Committee (CEP/ UFAL) with the opinion number 1.685 .464 and CAAE number 58743316.0.0000.5013.

To start the data collection the main researcher, who worked as a trainee of the units conducted an approximation of the research scenarios, with clarifications and explanations about the objectives, and, consequently, the interview with the subjects. The interviews were scheduled in accordance with the subjects' time availability, however when it was not possible on the scheduled date, because of the unavailability caused by the demand from the unit, the interview would be rescheduled.

The semi-structured interview was oriented by a script elaborated by the authors of the study, guided by questions that addressed the assistance given, since the admission of the newborn, to the need of the CPAP use with prong, the care given before, during and after therapy, and the form of registration of care by the professional. The interviews were recorded with an average length of 15 minutes. Subsequently, the interviews were transcribed and compiled in Word ${ }^{\circledR}$ document, and will be destroyed after five years. Four interviewees refused to record as audio, thus, their rights have been respected and the recording of data was done manually throughout the interview, to ensure the originality of the data.

The data collection was ended after achieving the data saturation ${ }^{15}$, in observing after repetitive readings of the interviews that there were a repetition in the answers given.

The data from the interviews were analyzed in accordance with the Content Analysis from the perspective of Bardin, considered as an empirical method, represented by a set of instruments of a methodological nature that allows to unveil in a critical way of the statements and speeches. Thus, the pre-analysis steps were undertaken that occurred through the material organization that came about through the material organization; followed by material exploration, through fluctuating readings of the interviews; and finally, the treatment with the result with the encoding and inference of the collected data, with posterior division into categories. ${ }^{16}$

The unit of analysis used was the theme. In this respect, the researcher proceeded to the analytical immersion into the content in searching for themes that related to the nursing care to the neonate with CPAP.
The NP and its steps 05 steps (Data collection/Investigation; Nursing Diagnoses; Planning of the Expected Results; Implementation of Nursing Care; Evaluation of Nursing Care) were used as reference for the inference of the content.

All research participants signed the Informed Consent Form and ensured the preservation of dignity, the respect to the autonomy and defense of vulnerability of human beings involved in the research, in accordance with the CNS Resolution 466/12, National Health Council/ Health Ministry (CNS/MS). In order to guarantee secrecy and anonymity, the name of the professional was coded according to the professional category and number corresponding to the order of carrying out the interview, to describe: Nurse (E01); Nursing Technician (TE02); Nursing Auxiliary (AE03).

\section{RESULTS}

Thirty (30) professionals of the nursing team of two research scenarios units have participated, of which $12(40 \%)$ nurses, 16 $(53.3 \%)$ nursing technicians and two $(6.7 \%)$ nursing auxiliaries. Of these, only two professionals were men. With regards to age of the interviewees, the most $(40 \%)$ was between 30 and 39 years old. There was a predominance of two to five years $(46.7 \%)$ as for the time of professional experience, and $70 \%$ did not have any specific training in the neonatology area.

From the understanding of the professionals' statements, the following categories were identified: Nursing team care to the neonate using nasal CPAP with prong; and Nursing care records to the neonate with nasal prong CPAP.

\section{Category 1: Nursing team care to the neonate using nasal CPAP with prong}

The units that were scenario for the data collection are responsible for receiving neonates who present respiratory discomfort pictures, which requires that the professionals who work in that place can recognize the signals and symptoms arising from this syndrome. This initial moment of the nursing care corresponds to the first step of the NP (Data Collection/Investigation), and its establishment allows this susceptible group to have a safe and systematized care.

First we consider the gestational age, ok? I That the child was born, whether is a very pre-term baby, which is the ventilation assistance that it will need... (E11)

Well, in general, when we have with this discomfort we use the support that we have (...) to visualize the respiratory parameters and heartbeats (...) with these babies, we need to have a more reinforced attention here in the neo, doesn't it?! (TE11)

Thus, the professionals also reported the importance of adding to the data collection the carrying out of the physical exam, 
together with the anamnesis, and the due identification of the patterns presented by the patient.

He becomes dyspneic, the breathing is more intense (...) And also the heart rate that also accelerates a few. (AEO2)

The subcostal retraction, the vacillation of the nose wings and also the counting of the inspirations and expirations ... The color also, whether there is central cyanosis or only of the nail bed. (E12)

...we see whether it is with presence of cyanosis, we see its respiratory pattern ... (E08)

Observe nostril, vacillation of the nose wings, breathing in the abdomen area... Intercostal, these are the parameters of observation (...). (TE06)

From this initial evaluation, observing the parameters presented by the newborns, when questioned about the indication for the oxygentherapy use in the modality of nasal CPAP with prong, the interviewees answered:

(...) when they extubate the baby they try the CPAP to see how will be its breathing, until to promote weaning little by little. (TE04)

Those babies who don't support the hood, because sometimes the hood is installed in the baby, but it still remains under desaturation (...) (AEO2)

(...) NB that present apnea, but the most are premature of low weight, that don't support hood or that present cyanosis in ambient air, or in the hood. And also those who are submitted to weaning off the respirator. (E05)

The closer link between the phase of Nursing Diagnoses and the Planning of the nursing actions, shows the need that the professional nurse has in using the strategy of the reason and its ability to communicate with the other members of the nursing team, either for installation of the support or even for the maintenance and comfort care of the neonate. Thus, when asked on which actions should be taken before the installation of the nasal CPAP with prong, the interviewees answered:

Observe the weight of the baby and its size, put the cap, adapt to the prongs and the tracheas in the little body... In the small head of the baby and let then positioned in a way that do not press into the nostrils and in the nasal septum of the baby. (E06)
Before, I think that we also have to see the question of the nostril, in order to see how its nostril is (...) Also, the question of deviation, because there are many babies that have nasal septum deviation. If they "had" with "nasal" tube we need to transfer to the oral tube in order to make it possible for it to eat too. I think that is practically this. (E10)

The possible consequences with the installation of the nasal CPAP with prong were also mentioned by the professionals, exemplified by the following talk:

Pneumothorax, nasal septal injury, abdominal distension... (E01)

The maintenance of the system is one of the activities that can be carried out by all team members. However, there is fragility in relation the training of technical and auxiliary level professionals, in agreement with what was revealed during the professionals' characterization. Even with the offers available from the institution where they work, there is still as justification the lack of time, or work overload, which prevent them from participating in these courses.

(...) Another thing is also a training because only the nurses who carry out and do not train us, the technicians. They only put it and finished. Only we who remain attentive to the child without knowing if it is correct or not... (TE13)

When asked about the care that must be carry out during the use of the nasal CPAP with prong, the professionals showed in their speeches their concern in the carrying out of care that are cited in the literature, as can be seen in the speeches below:

During the use we also worry about the application of "little serum" in the nostrils... Then, we also worry about the question related to the massage and with the nostrils. (E06)

During these moments, these are the care, we must use gently, instill serum, use the bandage, the little cap, aspirate, see whether it is really bubbling, the pressure...... The PEEP (...) (TE02)

The correct positioning of the nasal prongs was one of the most cited care in the participants' answers, since according to professionals' reports, it's real the discomfort observed in the neonates who use the prong, and results in restlessness, and, the subsequent friction with the skin.

Seeing whether the prong is well adapted, protection of the nasal septum, seeing permeability of nostril, knowing whether the tracheas are firmly attached on the baby's 
cephalic pole... Is... Seeing whether the system is functioning... (E05)

(...) the baby... It moves, then it has some easiness on removing the prong. Then we must take care of the prong in order to it does not go out by the nostril and whenever it removes we must replace. (TE14)

In the scenarios, nasal protectors are used and cut empirically in a "pork snout" format as well as the hydrocolloid dressing in a T format. The applying of these protectors in the neonates under use of nasal CPAP with prong was one of the more cited nursing care in the professionals' answers in the face of local injuries prevention.

There must be the "piggy" that small portion that we put of flexible material in order to not having contact with the nostril, with the baby's nasal septum (...) (AE02)

Here I have never seen baby with many injuries of septum because we take care to do what we call "piggy" to protect the septum (...) (E07)

When asked about the care that must be carried out after the neonates be released of the CPAP, the interviewees answered:

After, monitoring evolution, know recognizing signals of respiratory discomfort, pulse oximetry ... (E02)

And after the use of CPAP... The baby who are released from CPAP we must take care to observe the respiratory pattern (...) (E04)

The use of protocols in research scenarios was presented as a constant concern by the professionals, although is a practice that have not been implemented yet, as can be observed in the answers:

... These protocols, we have not had established, we are in stage of development of the protocols. But we have a routine of orientations together with the physiotherapists that we adopted for injury prevention and to obtain better result in the CPAP use (E11)

I don't know, but the nurses are already doing. (TE13)

\section{Category 2: Nursing care records to the neonate under nasal CPAP use with prong}

In research scenarios the findings and interventions realized are recorded in proper sheet, getting in easy access for consultation. Through which one carries out the evaluation of the Nursing
Assistance, fifth phase of the PE, at all times during the assistance provided. The records were carried out at the following times:

At admission and daily, at the time of the visit when passing the map. (E01)

Mainly at the time of admission, when we'll carry out the nursing evolution, when we'll pass the map because we can get a general view. (E02)

(...) the map which has all main characteristics related to the baby (...). (E03)

In the units, sometimes, the overcrowding and the insufficient number of computers are shown as difficulties of maintaining an updated record in the electronic medical record, as shown in the statements below:

The record is done through electronic medical record and also we have own nursing records, as the map that has all main characteristics related to the baby ... (EiO3)

We have the electronic medical record, but we have a great difficulty because we do not have the adequate number of equipment in the sector yet... (E11)

(...) we do not have a wealth of records, doesn't it... do not have a wealth of records, don't it... We use to say that is on account of the work process that is tumultuous, and really it is. But not always the tumult of the work process justifies... (E08)

Furthermore, the insecurity of the professionals about the type of nursing records that must be carried out by each professional category was perceptible, running up, once more, against the need noted by the team of updates and trainings:

There is the nursing evolution, in which whenever one has an intercurrence related to this we write. (AE02)

A normal nursing evolution... (TE03)

(...)Reports that... write in the nursing evolution (...) (TE06)

\section{DISCUSSION}

In many statements of the interviewees, there was concern of citing a care that combined the use of clinical technologies and a humanized and individualized assistance, mainly when it concerns respiratory therapies. Emphasizing the need for participation in trainings and courses that deepen the knowledge 
acquired throughout their trainings and their practice in neonatal units. And also, the relationship between doings and practices of several professionals in order to reach the transdisciplinary of the assistance provided.

The prematurity consists in a relevant risk factor for development of respiratory disturbances. The premature neonates has characteristics that can compromise the realization of the gas exchanges, and as characteristics of this group the disadvantages resulting from the immaturity of the respiratory system and the disadvantages in the respiratory mechanics. ${ }^{17,18}$

A study conducted in the State of Piauí, which had as objective to determine the association between the predisposing factors of the admission of the newborn in the NITU and the maternal characteristics, demonstrated that $57.2 \%(n=215)$ of the neonates presented some respiratory problem as a diagnosis to its admission. ${ }^{19}$

This relationship between the prematurity and the respiratory disturbances was emphasized in the statements of the interviewees, when these report that as soon as the neonates are admitted, at the time of the data collection they seek initially information that allow reference to some of these two characteristics.

Since the Respiratory Distress Syndrome (RDS) is a condition characterized by respiratory failure generally related to delivery and premature birth and the consequences of these events, it is necessary to carry out observation and inspection of the neonates, since changes in respiratory pattern, increases in the respiratory work, color changes, the presence of tachypnea, intercostal and diaphragmatic retractions, expiratory whimpering, vacillation of nose wings in neonates are some of the signals and symptoms presented. ${ }^{13,20}$

The physical examination in addition to being of great importance for the data collection, is also closely related to the second phase of the NP, Nursing Diagnoses, since its findings may support the professionals in their decisions. ${ }^{21}$ However, it is stressed that this second stage of the NP has to be privately implemented by the nurse professional. ${ }^{11}$

Then, at this stage, the nurse professional needs to apply its academic expertise allied to its clinical decision to carry out the differential of its assistance decisions. Thus, at the second stage of the NP the interpretation and grouping of data that were collected in the anterior stage occurs. In this way, culminates in decisions that will support the selection of actions or interventions taken with the objective of reaching the results awaited. ${ }^{11}$

For assistance to RDS, for years, the mechanical ventilation was the method of first choice for these neonates, since the objective was to reduce the respiratory effort caused by the syndrome. These days, it is decided to the Noninvasive ventilation (NIV) and the CPAP as oxygentherapy methods of first choice. ${ }^{22}$

The interviewees mentioned the indications of use of nasal CPAP associated with prong in agreement with the literature about its early use in low weight neonates (birth weight less than 1,500 grams) and who present signals of respiratory effort since birth; neonates with weight less than 1,500 grams, and that present oxygen saturation less than $89 \%$ in oxygen equal to or above $40 \%$; in cases of post-tracheal extubation in any neonate with less than 1,500 grams; and in cases of neonatal apnea. ${ }^{20}$

However, despite the advances achieved to date the use of the nasal CPAP associated with prong can cause iatrogenic events. Among the problems cited in the literature are the erythema, the nasal congestion, lesions and pain on the face, discomfort, irritation, aspiration pneumonia, hypotension, pneumothorax, bronchoaspiration and abdominal distension. ${ }^{23}$

The CPAP installation are of responsibility of the nurse, however, the involvement and the constant surveillance of all members of the nursing team is indispensable for an appropriate installation and maintenance of the system. As well as the carrying out of constant trainings and qualifications courses with the whole health team. ${ }^{8,24}$

However, most interviewees did not have specialization in neonatology. And even with the offer of the institution of specific capacitation courses in neonatal care, as is the case of the nasal CPAP associated with prong, there are still some factors that makes it difficult for the participation of the professionals. Whether these factors are caused either by the work overload or by the lack of access to the courses.

Neonates under use of CPAP associated with the nasal prong need to be cared for a specialized care, not only regarding the respiratory disorders as discussed, as well as to injuries and iatrogenic events that are affected by the need to use this nasal interface for ventilation support. This can refer to the appearance and development in varying degrees of injuries in mucous nasal areas due to the integumentary immaturity prematurity-associated. ${ }^{1,9}$

In order to avoid the appearance of injuries the nurses have considered different forms of care and technologies with the objective of protecting the fragile nasal tissue of the neonates. The most cited material for the protection in the national and international literature is the hydrocolloid, that is made of cellulose, gelatin and pectin, which adheres to the skin and prevents the prongs friction with the skin of the nose. $8,25,26$

It was a constant concern during the professionals' interviews in referring to the importance and need of using nasal protectors in neonates under oxygen therapy when used the nasal prong with the CPAP, in order to prevent the appearance of nasal injuries. For this purpose, the use of protectors manufactured with hydrocolloid material, empirically in a "pork snout" or in a T format, when adapting the best adequacy to the neonates' nose was mentioned by the interviewees.

The third step of the NP comprises the Planning of the Expected Results and must permeate all nursing care provided, the intended results are sought through the nursing actions and interventions to be carried out. ${ }^{11}$ This step occurs concurrently with the recognition the need of the CPAP use, its installation and maintenance.

In the fourth step of the NP, Implementation of Nursing Care, the nursing interventions are carried out. ${ }^{11}$ With the use of the nasal CPAP associated with prong, some interventions are needed, such as: oropharyngx and nasopharyngx aspira- 
tion using lower caliber tubes to avoid the obstruction; the nasal septum massage with the aim of promoting the comfort being an excellent way of avoiding the formation of traumas in the nasal region; the monitoring of gas flow; the removal of the excess water from the tubes; the instillation of saline solution every 2 hours; prong proper fixation; the use of small cap which is fundamental to protect the neonates'scalp. 1,23,27

Among the care the good positioning of the nasal prong is essential, and this happens when it does not deform the neonate's face, does not compress the nasal septum and does not allow the displacement of the interface in the nostrils' internal part. ${ }^{4}$

Thus, there is the need for implementation of nursing actions in a systematized and standardized way, which aims at the best oxygenation and the reduction of the possible adverse effects caused by the use of the nasal CPAP with prong..$^{23}$ It is fundamental to implement protocols attached to its implementation rigidly in the care of neonates under NIV with other nursing care to aid in preventing some adverse effects of nasal CPAP use with prong. ${ }^{6}$ The implementation of the protocols are expected to reduce the iatrogenic events caused by the use of nasal CPAP nasal with prong..$^{23,24,28}$

It was noticeable the concern of the interviewees in formulating care protocols for the neonates in use of prong. However, it was still possible to note the distance of some professionals in participating in the creation of these protocols. With attitudes that many times demonstrated passing the responsibility of this creation only on the members of the management of the sector. What shows the need for interaction among the categories.

The evaluation of the assistance is dependent on the leadership of nurses for its implementation and the carrying out, in order to achieve the nursing expected results for the neonate. Thus, the routines of care developed by the nursing professionals must be recorded. To this end, it is up to the nurse to carry out the evolution of its care, being this the record after the evaluation of the general condition of the neonate. ${ }^{11}$

The insufficient number of health professionals; some administrative activities and practices are prioritized to the detriment of the records; lack of routine in using computerized systems for the record; little recognition of the NP as an instrument to organize the doing in nursing; and the own fear in handling electronic systems, are pointed out as difficulties for the maintenance of updated records. ${ }^{21}$

Moreover, the resolution COFEN 358/2009 establishes that the carrying out of the Nursing Evolution is privative to the nurse. ${ }^{11}$ Thus, the nursing annotation must be carried out by all nursing team, punctually, with gross data related to the patient and register an observation. Unlike the nursing evolution, since it is the responsibility of the nurse, it relates to the 24 hour period, it has a reflection and analysis of the patient's data. ${ }^{29}$

\section{FINAL CONSIDERATIONS}

Although the nurse has the knowledge about the care to be taken to the neonate under nasal CPAP associated with prong, the same cannot be evidenced in the statements of the medium level professionals of the nursing team, mainly with regards to the need for updates and qualification courses which prepare them in a better way for the specialized care required for this ventilation therapy.

There are still divergences regarding the application of the Nursing Process and the Nursing Care Systematization. Since in many cases it was possible to perceive that the professionals were able to correlating them in their statements, but pointed out difficulties to apply them in its daily practice in the units.

The professionals interviewed correlated the formation of nasal injuries in the neonates who use the nasal CPAP nasal with prong with the assistance taken, and demonstrated concern with its prevention, detection, evaluation and treatment of the possible consequences.

There is a need for researches to contribute on improving the nursing care of the neonates that use nasal CPAP with prong and of studies that focuses on the prevention of nasal lesions that could be caused by its use.

The realization of the research in a single hospital is pointed out as limitation of the study. As implication for practice we have the unveiling of the care of the neonate under use of nasal CPAP nasal with prong, by envisioning the advances already achieved and the difficulties still faced by the health team to implement a systematized care.

\section{FINANCIAL SUPPORT}

Institutional Program of Scientific Initiation Scholarships (PIBIC - CNPq/UFAL/FAPEAL - 2015/2016/2017) awarded to Bruna Luizy dos Santos Guedes in the years 2015 to 2017.

\section{REFERENCES}

1. Sousa NFC, Bonfim SFSF, Vasconcelos MGL, Bezerra JLO, Silva DVC Leal LP. Prevalência de lesão do septo nasal em prematuros no uso de prongas nasais. Rev Esc Enferm USP [Internet]. 2013 Dec; [cited 2017 Apr 24]; 47(6):1285-90. Available from: http://www.scielo.br/scielo. php?script=sci_arttext\&pid=S0080-62342013000601285\&lng=en\&nr $\mathrm{m}=$ iso

2. Tadielo BZ, Neves ET, Arrué AM, Silveira A, Ribeiro AC, Tronco CS, et al. Morbidade e mortalidade de recém-nascidos em tratamento intensivo neonatal no sul do Brasil. Rev Soc Bras Enferm Pediatr [Internet]. 2013 [cited 2018 Jan 27]; 13(1):7-12. Available from: https://sobep.org.br/ revista/component/zine/article/163-morbidade-e-mortalidade-de-recmnascidos-em-tratamento-intensivo-neonatal-no-sul-do-brasil.html

3. Tamez RN. Enfermagem na UTI neonatal: assistência ao neonato de alto risco. 5a ed. Rio de Janeiro: Guanabara Koogan; 2013. 355 p.

4. Brunherotti MAA, Martinez FE. Influência da posição corpora no deslocamento da pronga nasal em recém-nascido pré-termo em pressão positiva contínua em vias aéreas. Rev Paul Pediatr [Internet]. $2015 \mathrm{Jul} / \mathrm{Sep}$; [cited 2017 Apr 21]; 33(3):280-5. Available from: http://www.scielo.br/scielo.php?script=sci_arttext\&pid=S010305822015000300280\&lng=en\&nrm=iso

5. Wing R, Armsby CC. Noninvasive Ventilation in Pediatric Acute Respiratory IIIness. Clin Pediatr Emerg Med [Internet]. 2015; [cited 2018 Nov 22]; 16(3):154-62. Available from: https://www.sciencedirect.com/ science/article/pii/S1522840115000439

6. Bonfim SFSF, Vasconcelos MGL, Sousa NFC, Silva DVC, Leal LP. Lesão de septo nasal em neonatos pré-termo no uso de prongas nasais Rev Lat Am Enferm [Internet]. 2014; [cited 2017 Apr 21]; 22(5):826- 
33. Available from: http://www.scielo.br/scielo.php?script=sci_ arttext\&pid=S0104-11692014000500826\&lng=en\&nrm=iso

7. Günlemez A, Isken T, Gökalp AS, Türker G, Arisoy EA. Effect of Silicon Gel Sheeting in Nasal Injury Associated with Nasal CPAP in Preterm Infants. Indian Pediatr [Internet]. 2010 Mar; [cited 2017 Apr 21]; 47:2657. Available from: http://www.indianpediatrics.net/mar2010/265.pdf

8. Nascimento RM, Ferreira ALC, Coutinho ACFP, Veríssimo RCSS. Frequência de lesão nasal em neonatos por uso de pressão positiva contínua nas vias aéreas com pronga. Rev Lat Am Enferm [Internet]. 2009 Jul/Aug; [cited 2017 Abr 21]; 17(4):489-94. Available from: http://www.scielo.br/scielo.php?script=sci_arttext\&pid=S010411692009000400009\&lng=en\&nrm=iso

9. Newnam KM, McGrath JM, Estes T, Jallo N, Salyer J, Bass WT. An integrative review of skin breakdown in the preterm infant associated with nasal continuous positive airway pressure. J Obstet Gynecol Neonatal Nurs [Internet]. 2013 Sep/Oct [cited 2018 Nov 22]; 42(5):50816. Available from: https://www.ncbi.nlm.nih.gov/pubmed/24020476

10. Silva RS, Almeida ARLP, Oliveira FA, Oliveira AS, Sampaio MRFB, Paixão GPN. Sistematização da Assistência de Enfermagem na Perspectiva da Equipe. Enferm Foco [Internet]. 2016; [cited 2017 Apr 24]; 7(2):32-6. Available from: http://revista.cofen.gov.br/index.php/ enfermagem/article/view/803

11. Conselho Federal de Enfermagem (BR). Resolução $N^{\circ} 358$, de 15 de outubro de 2009. Dispõe sobre a Sistematização da Assistência de Enfermagem e a implementação do Processo de Enfermagem em ambientes, públicos ou privados, em que ocorre o cuidado profissional de Enfermagem, e dá outras providências. Brasília (FD): Conselho Federal de Enfermagem; 2009. [cited 2017 Apr 21]. Available from: http://www.cofen.gov.br/resoluo-cofen-3582009_4384.html

12. Souza MFG, Santos ADB, Monteiro Al. O processo de enfermagem na concepção de profissionais de Enfermagem de um hospital de ensino. Rev Bras Enferm [Internet]. 2013 Mar/Apr; [cited 2017 Apr 24]; 66(2):167-73. Available from: http://www.scielo.br/scielo. php?script=sci_arttext\&pid=S0034-71672013000200003\&lng=en\&n $\mathrm{rm}=$ iso

13. Pereira JA, Escobar EMA. Cuidados de Enfermagem ao RecémNascido Prematuro com Síndrome do Desconforto Respiratório: Revisão Integrativa. Rev Saúde Foco (Teresina) [Internet]. $2016 \mathrm{Jul} /$ Dec; [cited 2017 Apr 24]; 3(2):17-36. Available from: http://www4.fsanet. com.br/revista/index.php/saudeemfoco/article/view/1324

14. Polit DF, Beck CT. Fundamentos de pesquisa em enfermagem: avaliação de evidências para a prática da enfermagem. 7a ed. Porto Alegre: Artmed; 2011.

15. Fontanella BJB, Ricas J, Turato ER. Amostragem por saturação em pesquisas qualitativas em saúde: contribuições teóricas. Cad Saúde Pública (Rio de Janeiro) [Internet]. 2011 Jan; [cited 2017 Apr 21]; 24(1):17-27. Available from: http://www.scielo.br/pdf/csp/v24n1/02.pdf

16. Bardin L. Análise de conteúdo. São Paulo: Edições 70; 2011. 229 p.

17. Lanza FC, Barcellos PG, Dal Corso S. Benefícios do decúbito ventral associado ao CPAP em recém-nascidos prematuros. Fisioter Pesq [Internet]. 2012; [cited 2017 Apr 21]; 19(2):135-40. Available from: http:// www.scielo.br/pdf/fp/v19n2/08.pdf

18. Arrué AM, Neves ET, Silveira A, Pieszak GM. Caracterização da morbimortalidade de recém nascidos internados em unidade de terapia intensiva neonatal. Rev Enferm UFSM [Internet]. $2013 \mathrm{Jan} / \mathrm{Apr}$; [cited 2017 Apr 21];3(1):86-92. Available from:https://periodicos.ufsm.br/reufsm/ article/view/5947
19. Lages CDR, Sousa JCO, Cunha KJB, Silva NC, Santos TMMG. Fatores preditores para a admissão do recém-nascido na unidade de terapia intensiva. Rev Rene [Internet]. 2014 Jan/Fev; [cited 2017 Apr 21]; 15(1):311. Available from: $h$ ttp://periodicos.ufc.br/rene/article/view/3068

20. Ministério da Saúde (BR). Secretaria de Atenção à Saúde. Atenção à Saúde do Neonato: Guia para os Profissionais de Saúde. Brasília (DF) Ministério da Saúde;2014. [cited 2017 Apr 24]; Available from: http://bvsms. saude.gov.br/bvs/publicacoes/atencao_saude_recem_nascido_v3.pdf

21. Souza KV, Assis LTM, Chianca TCM, Ribeiro CL, Gomes AC, Lima RJ. Roteiro de coleta de dados de enfermagem em alojamento conjunto: contribuições da articulação ensino-serviço. Esc Anna Nery [Internet].2012 Apr/Jun; [cited 2017 Apr 22]; 16(2):234-9. Available from: http://www.scielo. br/scielo.php?script=sci_arttext\&pid=S1414-81452012000200004\&lng= en\&nrm=iso

22. Ota NT, Davidson J, Guinsburg R. Lesão nasal precoce pelo uso da pronga nasal em neonatos prematuros de muito baixo peso: estudo piloto. Rev Bras Ter Intensiva [Internet]. 2013; [cited 2017 Apr 24]; 25(3):245-50. Available from: http://www.scielo.br/pdf/rbti/v25n3/0103507x-rbti-25-03-0245.pdf

23. Silva DM, Chaves EMC, Farias LM, Lélis ALPA. Uso de pressão positiva contínua das vias aéreas em neonatos: conhecimento da equipe de enfermagem. Rev Rene [Internet]. 2010; [cited 2017 Apr 24]; 11(no. spe):195-203. Available from: http://www.periodicos.ufc.br/rene/article/ viewFile/4707/3499

24. Melo RCJ, Souza IEO, Paula CC. Enfermagem neonatal: o sentido existencial do cuidado na unidade de terapia intensiva. Rev Bras Enferm [Internet]. 2013; [cited 2017 Apr 21]; 66(5):656-62. Available from: http:// www.scielo.br/scielo.php?pid=S0034-71672013000500003\&script=sci_ abstract\&ting=pt

25. Reis LS, Silva EF, Waterkemper R, Lorenzini E, Cecchetto FH. Percepção da equipe de enfermagem sobre humanização em unidade de tratamento intensivo neonatal e pediátrica. Rev Gaúcha Enferm [Internet].2013; [cited 2017 Apr 24]; 34(2):118-24. Available from: http://www.scielo.br/scielo. php?script=sci_arttext\&pid=S1983-14472013000200015\&lng=en\&nrm =iso

26. Xie LH. Hydrocoloide dressing in preventing nasal trauma econdary to nasal continuous positive airway pressure in preterm infants. World $J$ Emerg Med [Internet]. 2014; [cited 2018 Nov 22]; 5(3):218-22. Available from: https://www.ncbi.nlm.nih.gov/pubmed/25225588

27. Primo CC, Baratela MS, Valladares MLP, Alvarenga SC, Lima EFA, Leite FMC. Fatores de risco associados à lesão nasal por dispositivo de pressão positiva em recém- nascidos. Rev Enferm UERJ [Internet].2014 Jan/Fev; [cited 2017 Apr 24];22(1):16-21. Available from: http://www.facenf.uerj.br/ v22n1/v22n1a03.pdf

28. Malagoli RC, Santos FFA, Oliveira EA, Bouzada MCF. Influência da posição prona na oxigenação, frequência respiratória e na força muscular nos neonatos pré-termo em desmame da ventilação mecânica. Rev Paul Pediatr [Internet]. 2012 Jun; [cited 2017 Apr 21]; 30(2):251-6. Available from: http://www.scielo.br/scielo.php?script=sci_arttext\&pid=S010305822012000200015\&lng=en\&nrm=iso

29. Conselho Federal de Enfermagem (BR). Resolução $N^{\circ} 0514,5$ de maio de 2016 Aprova o Guia de Recomendações para os registros de enfermagem no prontuário do paciente, com a finalidade de nortear os profissionais de Enfermagem. Brasilia (DF): Conselho Federal de Enfermagem;2016. [cited 2017 Abr 21]. Available from: http://www.cofen.gov.br/resolucaocofen-no-05142016 41295.html

\footnotetext{
${ }^{a}$ Article extracted from the da monograph - The Care of the Newborn under Use of Continuous Positive Airway Pressure:Vision of the Nursing Team. Authorship of Bruna Luizy dos Santos Guedes. Federal University of Alagoas. 2017. Linked to the research "Development of a nasal protector prototype for neonates: study of biometric measures for the use of prongs", coordinated by the Doctor Professor Ingrid Martins Leite Lúcio.
} 